\title{
Learning styles for medical students: role of VARK modality [Response to Letter]
}

This article was published in the following Dove Press journal:

Advances in Medical Education and Practice

\author{
Rachna Parashar \\ Sandip Hulke' \\ Abhijit Pakhare ${ }^{2}$ \\ 'Department of Physiology, AllMS \\ Bhopal, Bhopal, Madhya Pradesh 462024, \\ India; ${ }^{2}$ Department of Community and \\ Family Medicine, AlIMS Bhopal, Bhopal, \\ Madhya Pradesh 462024, India
}

\section{Dear editor}

It is really good on your part to show your interest in the article and putting your valid views.

As you have pointed out:

1. The author highlighted that kinaesthetic and aural forms of learning are preferred by early year medical students; it also concludes that a multimodal approach is best for enhanced learning. We agree that a multifaceted approach should be used, but how is it applied. - Through VARK modality, we have touched the sensory domain for perception. Changing teaching styles during digitization has motivated us to study this topic.

You are right, a multimodal approach should be used, With reference to Table 2 in our study, it was suggested that among four learning styles there was relatively more preference for aural and kinesthetic styles, which means considering a multimodality approach too.

2. Identified learning styles exhibited by students by using our distinct styles; there is little evidence to suggest that this model which attempts to valid. Instead, it is suggested that there are learning preferences exhibited by students, rather than a few distinct styles. - Study suggested by Papanagnou et al and Peyman et al may prove it is valid to use VARK as a study tool for classification of learners based on sensory modality. ${ }^{1-3}$

3. We hold the view that pedagogy should be classified in accordance to the topic being covered. In our experience, different modules require different facets of teaching. - Here we have taken the classification of learners based on sensory modality that generally touches almost every aspect of learning preferences, such as how case-based learning reflects the kinesthetic aspect.

Cadaver teaching in anatomy also reflects the kinesthetic and visual aspect of learning. Moreover, cadaver teaching is difficult to inculcate in the minds of learners until they have a better auditory explanation of it and we should not neglect other aspects like visual modal and reading and writing as the more you read the more you will be able to learn.

As you have rightly mentioned, keeping in mind the pedagogy of learning, we should do some cohort studies to prioritize the different methods of learning in medical education and studies should be done to match the academic performance. We are looking forward to study in this area.
Department of Physiology, AllMS Bhopal, TYPE V, All India Institute Residential Complex, Saket Nagar, Bhopal, Madhya Pradesh 462024, India

Tel +9l 9425 I 498 I

Email drrachnaparashar@rediffmail.com 


\section{Disclosure}

The authors report no conflicts of interest in this communication.

\section{References}

1. Peyman H, Sadeghifar J, Khajavikhan J, et al. Using VARK approach for assessing preferred learning styles of first year medical sciences students: a survey from Iran. J Clin Diagn Res. 2014;8(8):GC01GC04. doi:10.7860/JCDR/2014/8089.4667.
2. Brumpton K, Kitchener S, Sweet L. Learning styles in vertically integrated teaching. Clin Teach. 2013;10(5):282-286. doi:10.1111/ tct. 1202

3. Papanagnou D, Serrano A, Barkley K, et al. Does tailoring instructional style to a medical student's self-perceived learning style improve performance when teaching intravenous catheter placement? A randomized controlled study. BMC Med Educ. 2016;16 (1):205. doi:10.1186/s12909-016-0720-3

Dove Medical Press encourages responsible, free and frank academic debate. The content of the Advances in Medical Education and Practice 'letters to the editor' section does not necessarily represent the views of Dove Medical Press, its officers, agents, employees, related entities or the Advances in Medical Education and Practice editors. While all reasonable steps have been taken to confirm the content of each letter, Dove Medical Press accepts no liability in respect of the content of any letter, nor is it responsible for the content and accuracy of any letter to the editor.

Advances in Medical Education and Practice

Dovepress

\section{Publish your work in this journal}

Advances in Medical Education and Practice is an international, peerreviewed, open access journal that aims to present and publish research on Medical Education covering medical, dental, nursing and allied health care professional education. The journal covers undergraduate education, postgraduate training and continuing medical education including emerging trends and innovative models linking education, research, and health care services. The manuscript management system is completely online and includes a very quick and fair peer-review system. Visit http://www.dovepress.com/testimonials.php to read real quotes from published authors. 